\title{
The effect of fluid shear stress in hydrogen sulphide production and cystathionine $\gamma$-lyase expression in human early endothelial progenitor cells
}

\author{
Qingsong Hu${ }^{1 \#}$, Baojian Zhang ${ }^{2 \#}$, Yulong Liu ${ }^{3 \#}$, Yiqun Guo ${ }^{4}$, Tao Zhang ${ }^{1}$, Ruqiong Nie ${ }^{5}$ Xiao $\mathrm{Ke}^{6}$, \\ Xiaobian Dong ${ }^{1}$
}

${ }^{1}$ Department of Cardiology, First Affiliated Hospital of Jinan University, Guangzhou, China; ${ }^{2}$ Cardiac Care Unit, Affiliated Hospital of Traditional Chinese Medicine, Xinjiang Medical University, Urumqi, China; ${ }^{3}$ Department of Intervention and Vascular Surgery, First Affiliated Hospital of Jinan University, Guangzhou, China; ${ }^{4}$ Department of Interventional Radiology and Vascular Anomalies, Guangzhou Women and Children's Medical Center, Guangzhou, China; ${ }^{5}$ Department of Cardiology, Guangzhou Province Key Laboratory of Arrhymia and Electrophysiology, Sun Yatsen Memorial Hospital of Sun Yat-sen University, Guangzhou, China; ${ }^{6}$ Department of Cardiology, Fuwai Hospital, Chinese Academy of Medical Sciences, Shenzhen, China

Contributions: (I) Conception and design: Q Hu, X Dong; (II) Administrative support: R Nie; (III) Provision of study materials or patients: Y Guo; (IV) Collection and assembly of data: T Zhang, X Ke; (V) Data analysis and interpretation: Y Liu, B Zhang; (VI) Manuscript writing: All authors; (VII) Final approval of manuscript: All authors.

\#These authors contributed equally to this work.

Correspondence to: Xiaobian Dong. Department of Cardiology, First Affiliated Hospital of Jinan University, Guangzhou, China.

Email: dongxiaobian0317@163.com.

Background: Physiological fluid shear stress has been shown to have a beneficial impact on vascular homeostasis. Endothelial progenitor cells (EPCs) make a significant contribution to maintaining endothelial integrity. Therefore, we hypothesised that shear stress-induced endothelium protection plays a role in hydrogen sulphide $\left(\mathrm{H}_{2} \mathrm{~S}\right)$ production and up-regulation of cystathionine $\gamma$-lyase (CSE) expression in EPCs.

Methods: Human EPC-derived CSE activity was detected by colorimetric assay, and $\mathrm{H}_{2} \mathrm{~S}$ production was evaluated by membrane adsorption method. Cell proliferation, migration, and adhesion were assessed by MTT, Transwell, and endothelial cell-mediated adhesion assays, respectively. Real-time polymerase chain reaction (RT-PCR) was carried out to analyse gene expression. Protein expression was analysed by western blot.

Results: Human EPCs were treated with shear stress levels of 5-25 dyn/ $\mathrm{cm}^{2}$ for up to 3 h, and $25 \mathrm{dyn} /$ $\mathrm{cm}^{2}$ for up to $24 \mathrm{~h} . \mathrm{H}_{2} \mathrm{~S}$ production and CSE mRNA expression in the EPCs were increased by shear stress in a dose-dependent manner in vitro. Likewise, time-dependent shear stress also significantly enhanced CSE protein expression. Compared to static condition, shear stress improved EPCs proliferation, migration and adhesion capacity. Knockdown of CSE expression by small interfering RNA substantially eliminated the shear stress-induced above functions of human EPCs in vitro.

Conclusions: This study gives new insight into the regulatory effect of physiological shear stress on the $\mathrm{CSE} / \mathrm{H}_{2} \mathrm{~S}$ system in human EPCs. Our findings may contribute to the development of vascular protective research, although the relevant evidence is admittedly indirect.

Keywords: Shear stress; endothelial progenitor cells (EPCs); hydrogen sulphide $\left(\mathrm{H}_{2} \mathrm{~S}\right)$; cystathionine $\gamma$-lyase (CSE)

Submitted Aug 26, 2020. Accepted for publication Oct 20, 2020.

doi: $10.21037 / \mathrm{atm}-20-6467$

View this article at: http://dx.doi.org/10.21037/atm-20-6467 


\section{Introduction}

Damage to the structure and functional integrity of the endothelium is widely understood to be a significant contributor to the pathogenesis of atherosclerosis $(1,2)$. The alteration of endothelial components can increase the risk for both traditional and atherosclerotic vascular disease $(3,4)$. Therefore, the acceleration of endothelial restoration should be a priority in medical research.

Endothelial progenitor cells (EPCs) derived from bone marrow or peripheral blood are crucial to preserving the integrity of the vascular endothelium after it has suffered damage and in atherosclerosis-prone vascular areas $(5,6)$. EPCs are categorised as either early or late EPCs depending on their phenotypic characteristics (7). Atherosclerosis are characterized by dysfunctional and numerically reduced early EPCs, and decreased numbers and impaired functions of circulating early EPCs are related to endothelial dysfunction and poor cardiovascular outcomes in patients with coronary artery disease $(8,9)$. Conversely, endogenous mobilization or systemic application of early EPCs leads to improvement of endothelial repair, enhancement of angiogenesis and endothelial function, decreased neointima formation, and reduced development of atherosclerosis (3,5-7). The effects of EPCs on vascular protection, however, are dependent on cystathionine $\gamma$-lyase (CSE) expression $(10,11)$. CSE is an enzyme that catalyses endogenous production of hydrogen sulphide $\left(\mathrm{H}_{2} \mathrm{~S}\right)(12)$. The CSE $/ \mathrm{H}_{2} \mathrm{~S}$ pathway exhibits various cardioprotective effects including anti-atherosclerosis, anti-hypertension, pro-angiogenesis, and the attenuation of myocardial ischemia-reperfusion injury (13-16). A number of recent animal studies have suggested that decreased CSE expression in EPCs may weaken their vaso-protective effects $(10,11)$. Therefore, amelioration of CSE expression in EPCs may be a viable strategy for cell-based treatments for cardiovascular disease.

Fluid shear stress is a frictional force induced by blood flow at the surface of the endothelium. Shear stress has a beneficial effect on vascular endothelium homeostasis and modulates many functional genes expression in EPCs (17). Previous research has demonstrated that increased levels of physical shear stress could enhance the in vitro functions and reendothelialisation capacity of EPCs $(18,19)$. Recent data also showed that shear stress facilitates the expression of endothelial nitric oxide synthase (eNOS), beta2adrenergic receptor ( $\beta 2 \mathrm{AR}$ ) and tissue-type plasminogen activator (t-PA) in human early EPCs $(20,21)$. Further,
Huang et al. reported that shear stress enhanced $\mathrm{H}_{2} \mathrm{~S}$ production in human endothelial cells (22), which suggests that CSE expression plays a role in shear stress-mediated regulation of the vascular endothelium. However, until recently, little data has been available to evidence the effects of shear stress levels on CSE expression in human EPCs. Considering the observations mentioned above, we hypothesised that fluid shear stress upregulates CSE expression and $\mathrm{H}_{2} \mathrm{~S}$ production in human EPCs, and works to promote enhanced EPC functions in vitro. Thus, the present study investigated shear stress and its effects on $\mathrm{H}_{2} \mathrm{~S}$ production and the mRNA and protein expression of CSE in human EPCs. It also examined the impact of CSE expression on the shear stress-mediated function of human EPCs in vitro. The findings of this study may give a deeper insight into shear stress and its effects on the function of EPCs, and inform the development of new strategies for improving EPC activity. We present the following article in accordance with the MDAR reporting checklist (available at http://dx.doi.org/10.21037/atm-20-6467).

\section{Methods}

\section{Culture and identification of early human EPCs}

Early human EPCs were isolated and cultured as described in previous studies $(23,24)$. Peripheral blood mononuclear cells (PBMNCs) were isolated from young, healthy individuals using Ficoll density gradient centrifugation at $400 \mathrm{~g}$ for $30 \mathrm{~min}$. The PBMNCs were then cleaned three times with phosphate-buffered saline (PBS). After centrifuged at $700 \mathrm{~g}$ for $10 \mathrm{~min}$, the collected PBMNCs were cultured on 6-well fiberonectin (FN)-coated plates in endothelial cell medium-2 (EBM-2) (Lonza, Basel, Switzerland), supplemented with EGM-2 Bullte Kit (Lonza) and $10 \%$ fetal bovin serum (FBS) (Gibco, MA, USA). After 4 days of culture, non-adherent cells were discarded, and adherent cells were cultured for a further 7 days before being used in the subsequent experiments. All experimental protocols in this study complied with the ethical principles laid out in the Declaration of Helsinki (as revised in 2013). The study protocol was approved by the Ethics Committee of the First Affiliated Hospital of Jinan University (Guangzhou, China). Informed consent was taken from all the subjects.

Any cells that were positive for both lectin binding and acetylated low density lipoprotein (AcLDL) uptake were considered to be EPCs. Cultured cells were incubated 
with Dil-AcLDL $(0.02 \mathrm{mg} / \mathrm{mL}$; Invitrogen, Carlsbad, CA, USA) for $2 \mathrm{~h}$. Following incubation, the cells were cleaned and fixed with $4 \%$ paraformaldehyde (PFA) for $15 \mathrm{~min}$ before incubation with fluorescein isothiocyanate (FITC)labelled UEA (Ulex europaeus) $(0.01 \mathrm{mg} / \mathrm{mL}$; Sigma, MO, USA) for $1 \mathrm{~h}$. After that, the cell plates were washed once more, then incubated with 4',6-diamidino-2-phenylindole (DAPI) nuclear counterstain. Double-positive cells were then examined with a fluorescent microscope $(\times 200$ magnification; Olympus, Japan).

\section{Flow cytometry analysis}

After 7 days of culture, endothelial marker proteins were analysed using flow cytometry with phycoerythrin (PE)-labelled monoclonal mouse anti-human antibodies recognising CD31 (BD Pharmingen, San Diego, CA, USA), kinase-insert domain receptor (KDR; R\&D System, Minneapolis, MN, USA), von Willebrand factor (vWF; R\&D System, Minneapolis, MN, USA), and CD14 (BD Pharmingen, San Diego, CA, USA). The expression levels of these surface antigens were determined by incubating the cells in $100 \mu \mathrm{L}$ of PE-labelled antibody or a corresponding IgG isotype control (Beckman Coulter, Fullerton, CA, USA) at $4^{\circ} \mathrm{C}$ for $30 \mathrm{~min}$.

\section{In vitro culture of EPCs with shear stress}

EPCs were exposed to shear stress using a flow chamber device as previously described (25). Cell-seeded glass plates were placed in the parallel-plate flow chamber. After $24 \mathrm{~h}$ of culture, adherent seeded cells on the parallel-plate flow chamber were exposed to 5,15 , or $25 \mathrm{dyn} / \mathrm{cm}^{2}$ laminar shear stress for up to $3 \mathrm{~h}$, or to $15 \mathrm{dyn} / \mathrm{cm}^{2}$ laminar shear stress for $30 \mathrm{~min}$. Laminar shear stress was calculated using the equation $\mathrm{T}=6 \mathrm{Qu} / \mathrm{bh}^{2}$, where $\mathrm{T}$ represents shear stress, $\mathrm{Q}$ represents flow rate, $\mathrm{u}$ represents medium viscosity, $\mathrm{b}$ represents channel width, and h represents channel height. The control group EPCs were stored in static conditions. Each assay was carried out at $37^{\circ} \mathrm{C}$ in a $\mathrm{CO}_{2}$ incubator.

\section{EPC proliferation test}

The proliferative activity of EPCs was determined using the MTT assay, as described in previous studies (26). Following 7 days of culture, EPCs were digested with $0.25 \%$ trypsin and seeded in the flow chamber to undergo shear stress treatment. After this treatment, the cells were cultured in 96-well culture plates $(200 \mu \mathrm{L} /$ well $)$ in serum-free medium for $24 \mathrm{~h}$. Then, $15 \mu \mathrm{L}$ MTT (10 g/L; Fluka, SigmaAldrich, USA) was added to the cells before incubation for a further $5 \mathrm{~h}$. The supernatant was then aspirated, and the cell preparation was shaken with $200 \mu \mathrm{L}$ dimethyl sulfoxide (DMSO) for $5 \mathrm{~min}$. Finally, the optical density value was measured at $490 \mathrm{~nm}$.

\section{EPC migration in vitro}

EPCs $\left(2 \times 10^{4}\right)$ were isolated, resuspended in $200 \mu \mathrm{L}$ cell medium, and injected into the superior chamber of a modified Boyden chamber after 7 days culturing (Costar Transwell system, $8-\mu \mathrm{m}$ pore size; Corning, USA). Then, the chamber was placed in a 24-well culture dish including $500 \mu \mathrm{L}$ cell medium, supplemented with $100 \mathrm{ng} / \mathrm{mL}$ SDF-1 (Stromal derived factor-1) (PeproTech, Rocky Hill, USA). After $5 \mathrm{~h}$ of culture in this solution, cells that had migrated to the lower chamber were stained with DAPI. Transmigrated cells were randomly counted by an independent investigator.

\section{Tumour necrosis factor (TNF)- $\alpha$-mediated cell adbesion assay}

A monolayer of human umbilical vein endothelial cells (HUVECs) was formed by seeding $2 \times 10^{5}$ cells in each well $48 \mathrm{~h}$ before the cell adhesion experiment. The HUVECs were pretreated with a $0.5 \mathrm{ng} / \mathrm{mL}$ concentration of tumour necrosis factor- $\alpha$ (TNF- $\alpha$; PeproTech, Rocky Hill, USA) for $15 \mathrm{~h}$. Following this pretreatment, $1 \times 105$ CM-Dillabelled cells (CM-Dil; Molecular Probe) were added to each well and incubated alongside the HUVECs at $37^{\circ} \mathrm{C}$ for $24 \mathrm{~h}$. Non-attached cells were then extracted using PBS. Finally, adherent EPCs were then fixed with 4\% PFA, and counted and recorded in five randomly-selected microscopic fields $(\times 200)$.

\section{CSE activity measurement}

CSE activity was established using colorimetric assay to determine pyruvate formation, as described in a previous study (27). Following different levels of shear stress treatment, the cells were collected and homogenised in $20 \mathrm{mM}$ of potassium phosphate buffer $(\mathrm{pH} 7.8)$. The homogenate was then centrifuged at 12,000 $\times \mathrm{g}$ for $20 \mathrm{~min}$ at $4{ }^{\circ} \mathrm{C}$. Supernatant $(20 \mu \mathrm{L})$ was then added to $170 \mu \mathrm{L}$ of $100 \mathrm{mM}$ Tris-phosphate buffer (pH 8.0) containing 
$2.35 \mathrm{mM}$ EDTA, $35 \mu \mathrm{M}$ pyridoxal 5'-phosphate, and $13.7 \mathrm{mM} \beta$-chloro-L-alamine. The mixture was then incubated at $37^{\circ} \mathrm{C}$ for $10 \mathrm{~min}$. The blank sample was prepared in a similar manner, but the sample was instead added to the substrate mixture. A Multiskan spectrum microplate spectrophotometer was used to measure green dye absorbance at $727 \mathrm{~nm}$. The CSE- activity was expressed as the balance of absorbance at $727 \mathrm{~nm} / \mathrm{mg}$ of protein.

\section{Evaluation of $\mathrm{H}_{2} \mathrm{~S}$ production}

The production rate of $\mathrm{H}_{2} \mathrm{~S}$ was measured using the methods described above (27). Following their respective treatments, cells were collected and homogenised in $50 \mathrm{mM}$ of ice-cold potassium phosphate buffer ( $\mathrm{pH} 6.8$ ). Flasks containing reaction mixture $(100 \mathrm{mM}$ potassium phosphate buffer, $10 \mathrm{mM}$ L-cysteine, $2 \mathrm{mM}$ pyridoxal 5'-phosphate, and $10 \%(\mathrm{w} / \mathrm{v})$ cell homogenates), the centre wells containing $0.5 \mathrm{ml} 1 \%$ zinc acetate, and a piece of filter paper were flushed with N2 and incubated for $90 \mathrm{~min}$ at $37{ }^{\circ} \mathrm{C}$. The reaction was stopped by adding $0.5 \mathrm{~mL}$ of $50 \%$ trichloroacetic acid to the solution. The flasks were then incubated again, at $37^{\circ} \mathrm{C}$ for $1 \mathrm{~h}$. The contents of the centre wells were then transferred to test tubes containing $3.5 \mathrm{~mL}$ of water, to which $0.5 \mathrm{~mL}$ of $20 \mathrm{mM} \mathrm{N}$,N-dimethlp-phenylenediamine sulfate in 7.2 M hydrogen chloride ( $\mathrm{HCl})$ and $0.5 \mathrm{~mL} 30 \mathrm{mM}$ ferric chloride $(\mathrm{FeCl} 3)$ in $1.2 \mathrm{M}$ $\mathrm{HCl}$ were then added. After $20 \mathrm{~min}$, the absorbance of the solution was measured at $670 \mathrm{~nm}$, using a Multiskan spectrum microplate spectrophotometer.

\section{CSE knockdown in EPCs}

Following 7 days of culture, cells $\left(1 \times 10^{5}\right.$ cells/well) were placed in 6-well plates and then incubated at $37^{\circ} \mathrm{C}$. Upon reaching $~ 70 \%$ confluency, the cells were kept in serumfree medium for $8 \mathrm{~h}$ before they were transfected with small interfering siRNA. EBM-2 media on CSE-siRNA (sc-78973, Santa Cruz Biotechnology) was diluted to a $10 \mu \mathrm{mol} / \mathrm{L}$ working solution and delivered into the cells at a final concentration of $5 \mu \mathrm{mol} / \mathrm{L}$ using an siRNA transfection reagent (sc-29528, Santa Cruz Biotechnology). The CSEsiRNA sequence was designed in Table S1. Following $6 \mathrm{~h}$ of transfection, the transfection medium was replaced with new EGM-2, and the cells underwent an additional $48 \mathrm{~h}$ of incubation. The cells were then cultured on glass slides for use in later shear stress flow treatment. An unrelated scrambled sequence siRNA (Control siRNA-A, sc-37007;
Santa Cruz Biotechnology) was used as a transfection control.

\section{Quantitative real-time polymerase chain reaction (RT- PCR) and western blot analysis}

Total RNA was extracted using TRIzol reagent (Invitrogen). Double-stranded DNA was synthesised using M-MLV Reverse Transcriptase (TaKaRa, Kusatsu, Shiga, Japan). RT-PCR was carried out using Light Cycler 480 SYBR Green I Master Mix (Roche Diagnostics, Risch-Rotkreuz, Switzerland) in a Light Cycler 480 System. The cycling protocol used was as follows: $95{ }^{\circ} \mathrm{C}$ for $5 \mathrm{~min}$, followed by 45 cycles of $95{ }^{\circ} \mathrm{C}$ for $10 \mathrm{~s}, 60^{\circ} \mathrm{C}$ for $10 \mathrm{~s}$, and $72{ }^{\circ} \mathrm{C}$ for $20 \mathrm{~s}$. The CSE and glyceraldehyde 3-phosphate dehydrogenase (GAPDH) primers used were seen in Table S2.

EPCs protein was harvested by cell lysis buffer (Cell Signaling Tech) in line with the manufacturer's instructions. Protein $(50 \mu \mathrm{g})$ was subjected to sodium dodecyl sulphatepolyacrylamide electrophoresis (SDS-PAGE) and then transferred to polyvinylidene fluoride (PVDF) membranes. The following antibody was used CSE (1:1,000, Abnova). Proteins were visualised with horseradish peroxidaseconjugated IgG (1:5,000, Cell Signaling Tech), followed by using of the ECL chemiluminescence system (Cell signaling Tech).

\section{Statistical analysis}

Data were expressed as the mean \pm standard error of the mean. The statistical significance of these findings was evaluated using Student's $t$-test or one-way ANOVA. Statistical significance was indicated by a $\mathrm{P}$ value of $\leq 0.01$. All statistical analyses were performed with SPSS statistical software (SPSS version 13.0; IBM Corporation, Armonk, NY, USA).

\section{Results}

\section{Characterisation of human early EPCs}

Before induction, the PBMNCs that were seeded in fibronectin-coated wells were mostly round in shape. However, after 1 week of culture, the PBMNCs appeared to have taken on a spindle-shaped form. In fluorescent immunocytochemical analysis, adherent cells were stained for both Dil-acLDL and FITC-lectin (Figure 1A). Comparable expression levels of endothelial marker 
A

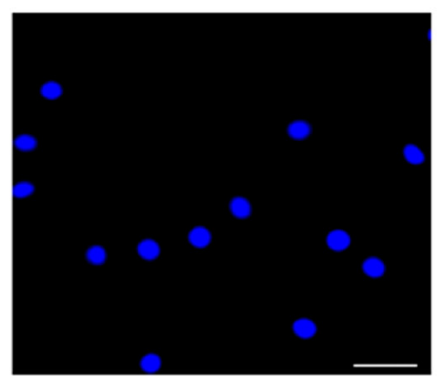

DAPI

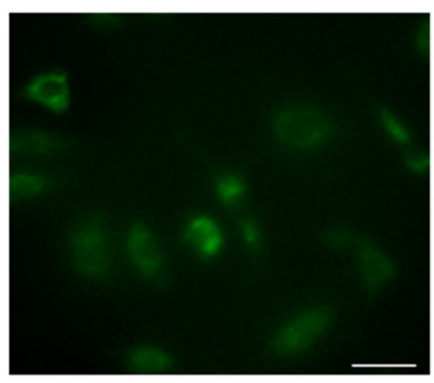

FITC-lectin

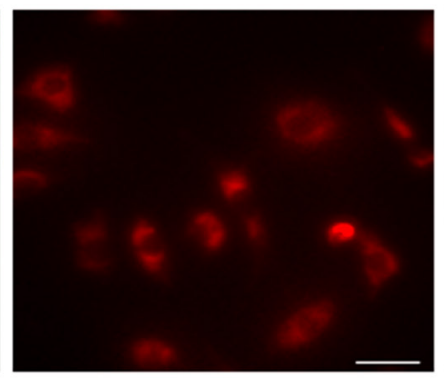

Dil-acLDL

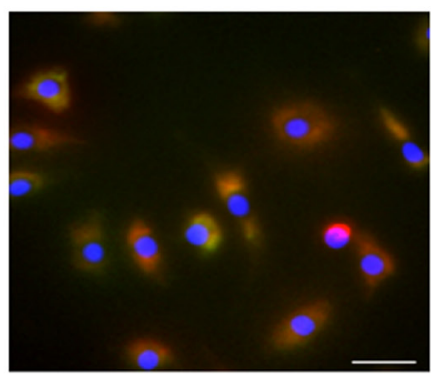

Merged

\section{B}

Flow cytometric analysis of EPCs
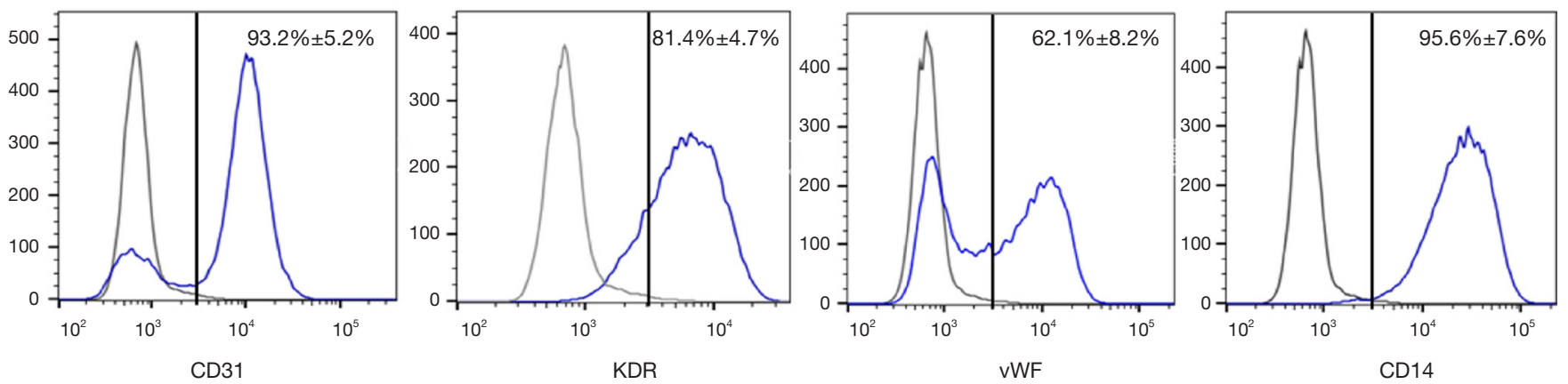

Figure 1 Characterization of cultured human early EPCs. (A) Representative photographs of EPCs on day 7 labelled with FITC-lectin (green), Dil-acLDL (red), and DAPI (blue), and a merged image ( $\times 200$ magnification). (B) Flow cytometry analysis of the endothelial markers CD31, vWF, KDR, and the monocytic lineage marker CD14 in EPCs (IgG isotype was the control, n=5 per group). Numbers are the mean \pm SEM percentage of positive cells for all experiments determined by comparison with the corresponding labelled negative control. EPC, endothelial progenitor cell; FITC, fluorescein isothiocyanate; DAPI, 4',6-diamidino-2-phenylindole; KDR, kinase-insert domain receptor.

proteins (KDR, vWF, and CD31) as well as the monocytic marker CD14 were also detected in adherent cells, which corresponded to the EPC phenotype previously mentioned (7) (Figure 1B). All the characterization above indicated that the cultured EPCs in this study could be classified into human early EPCs as previously.

\section{The effect of fluid shear stress on $\mathrm{H}_{2}$ S production in buman EPCs}

To ascertain the effect of shear stress on $\mathrm{H}_{2} \mathrm{~S}$ production, human EPCs were exposed to shear stress in vitro under 5,15 , or $25 \mathrm{dyn} / \mathrm{cm}^{2}$ for $3 \mathrm{~h}$. Human EPCs under static conditions served as the control group (Figure 2). The application of low to high levels of shear stress led to a gradual increase in $\mathrm{H}_{2} \mathrm{~S}$ production by EPCs. $\mathrm{H}_{2} \mathrm{~S}$ production induced by 5,15 and $25 \mathrm{dyn} / \mathrm{cm}^{2}$ shear stress increased 2.2-fold, 3.2-fold, and 4.3-fold respectively, compared to the control group ( $\left.\mathrm{n}=5,{ }^{*}, \mathrm{P}<0.05\right)$. Shear stressinduced $\mathrm{H}_{2} \mathrm{~S}$ production reached its highest levels at $30 \mathrm{~min}$. At this time, an initial surge in $\mathrm{H}_{2} \mathrm{~S}$ production was observed, and significantly increased levels of production were maintained for up to $3 \mathrm{~h}$. This observation is consistent with that previously reported about the fashion change of in $\mathrm{H}_{2} \mathrm{~S}$ production in shear stress-stimulated mature endothelial cells (20).

\section{The effects of fluid shear stress on CSE activity in buman EPCs}

To determine the effect of shear stress on $\mathrm{H}_{2} \mathrm{~S}$ activity, human EPCs were exposed to shear stress treatment in 


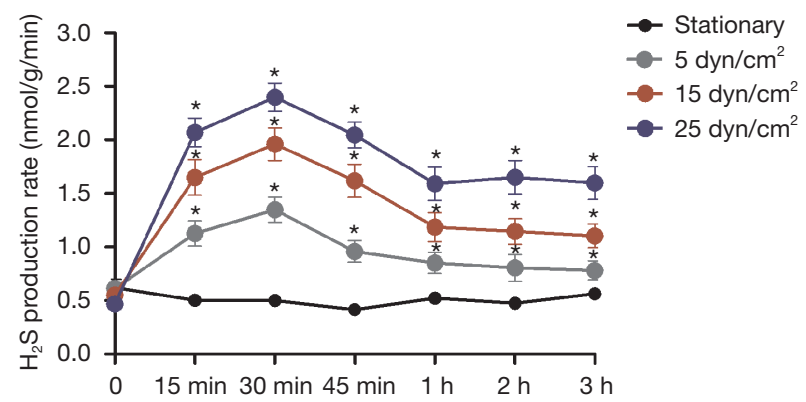

Figure $2 \mathrm{H}_{2} \mathrm{~S}$ production by human EPCs in response to different levels of shear stress. * $\mathrm{P}<0.05$ vs. stationary group. $\mathrm{H}_{2} \mathrm{~S}$, hydrogen sulphide; EPC, endothelial progenitor cell.

vitro, under 5,15 , or $25 \mathrm{dyn} / \mathrm{cm}^{2}$ for $30 \mathrm{~min}$. EPCs under static conditions served as the control group (Figure $3 A$ ). Dose-dependent increases in human EPC activity were observed as the shear stress levels gradually increased from low to high. 5, 15 and $25 \mathrm{dyn} / \mathrm{cm}^{2}$ Shear stress-induced CSE activity in human EPCs increased 2.5-, 3.0-, and 4.2-fold, respectively, compared to the control group ( $\mathrm{n}=5$, *, $\mathrm{P}<0.05)$.

\section{The effect of shear stress on CSE mRNA and protein expression in buman EPCs}

To determine the effects of shear stress on CSE mRNA expression in human EPCs, human EPCs were exposed to shear stress treatment in vitro, under 5,15 , and $25 \mathrm{dyn} / \mathrm{cm}^{2}$, respectively, for $3 \mathrm{~h}$. EPCs that did not undergo shear stress treatment served as a control group. The levels of CSE mRNA expression in human EPCs were observed to increase in a dose-dependent manner when EPCs were exposed to gradually increasing levels of shear stress (Figure $3 B$ ). Five, 15 and $25 \mathrm{dyn} / \mathrm{cm}^{2}$ Shear stress-induced CSE mRNA expression increased 1.9-fold, 2.37-fold, and 3.16fold, respectively, compared to the control group $(\mathrm{n}=5$, *, $\mathrm{P}<0.05)$. The impact of shear stress on CSE protein expression in human EPCs was also evaluated. EPCs were exposed to shear stress with $25 \mathrm{dyn} / \mathrm{cm}^{2}$ for 6,12 , and $24 \mathrm{~h}$, respectively. The expression of CSE in human EPCs was enhanced in a time-dependent manner compared to the control group $\left(\mathrm{n}=5,{ }^{*}, \mathrm{P}<0.05\right)($ Figure $3 C)$. These results suggested that shear stress could significantly increase the function of CSE in human EPCs.

\section{The effects of CSE expression on shear stress-medicated in vitro functions of human EPCs}

After 7 days of culture, human EPCs were exposed to shear stress in vitro, with $25 \mathrm{dyn} / \mathrm{cm}^{2}$ for $30 \mathrm{~min}$. To determine the influence of CSE expression on the shear stressenhanced functions of human EPCs, small interfering RNA was used to knockdown CSE expression. As shown by western blot analysis, CSE expression decreased by almost $70 \%$ after siCSE treatment (Figure $4 A$ ). Shear stress exposure led to increases in the proliferation and migration ability, and TNF- $\alpha$ activated adhesion, of human EPCs (Figure 4B,C,D). The shear stress-induced enhancement of human EPC functions in vitro above mentioned was mostly eliminated by siCSE (Figure $4 B, C, D$ ), indicating that any shear stress-enhanced in vitro EPC functions were at least partly facilitated by CSE expression.

\section{Discussion}

This study provides evidence to show that, in a dosedependent manner, fluid shear stress boosts CSE activity and $\mathrm{H}_{2} \mathrm{~S}$ production in early human EPCs. The shear stress-induced up-regulation of CSE mRNA and protein expression in human EPCs has also been shown to be responsible for enhanced synthesis of $\mathrm{H}_{2} \mathrm{~S}$. Moreover, the shear stress-induced functions (proliferation, migration, and adhesion) of EPCs in vitro have been shown to be at least partly mediated by CSE expression. These findings offer new evidence that indicates that the physiological levels of shear stress have a potentially beneficial effect on the regulation of the biological phenotype of EPCs. This alternative beneficial mechanism may contribute to shear stress-mediated vascular protection processes.

The endogenous production of $\mathrm{H}_{2} \mathrm{~S}$ and its physiological functions place this gas within the novel family of endogenous gasotransmitters, alongside nitric oxide (NO) and carbon monoxide (CO) (12). CSE has been proposed as one of the primary enzymes responsible for the generation of $\mathrm{H}_{2} \mathrm{~S}$ within the cardiovascular system. $\mathrm{H}_{2} \mathrm{~S}$ is largely expressed in cardiomyocytes, vascular ECs, smooth muscle cells, and progenitor cells $(11,12)$. Previous studies have indicated that CSE protein expression in bone marrow-derived EPCs is extremely low in cultures with static conditions (11), which suggests that upregulation of CSE expression and increased $\mathrm{H}_{2} \mathrm{~S}$ production in 


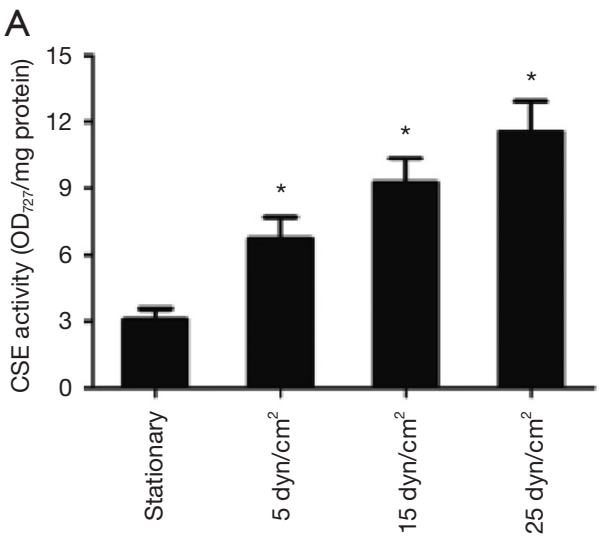

B

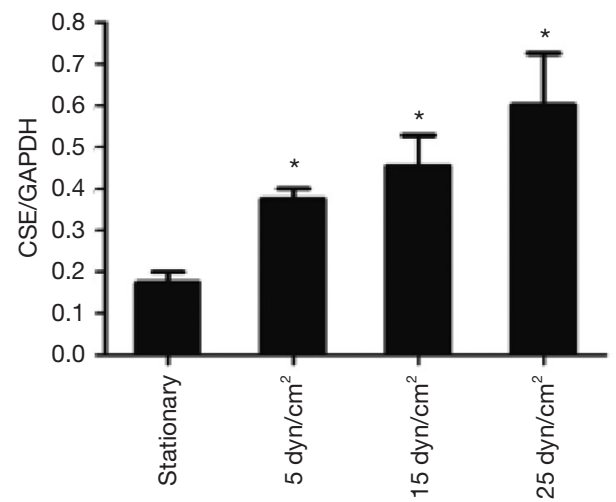

C
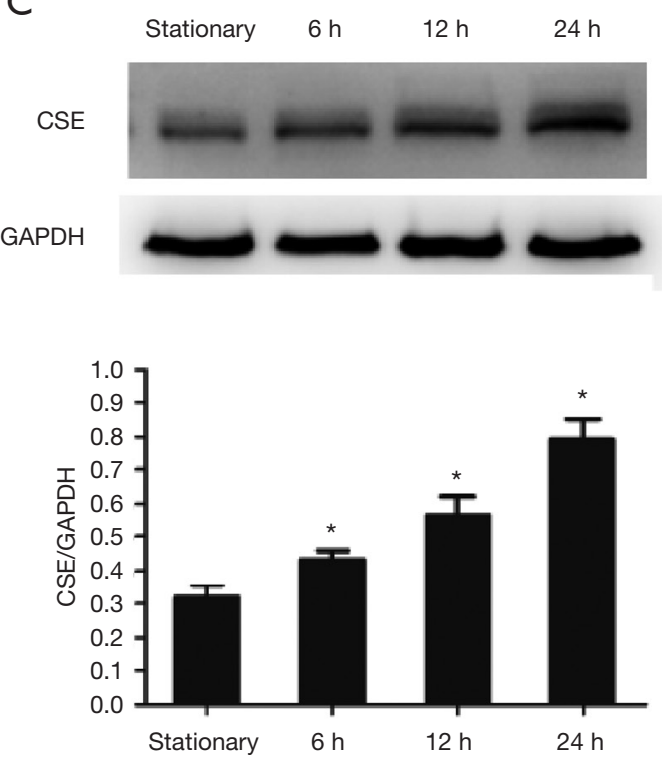

Figure 3 CSE activity (A), mRNA (B) and protein (C) expression in human EPCs in response to shear stress. *, $\mathrm{P}<0.05$ vs. stationary group. CSE, cystathionine $\gamma$-lyase; EPC, endothelial progenitor cell.

EPCs may enhance the biology of EPCs and benefit the vascular protective processes they mediate. Our group believes that preconditioning with exogenous $\mathrm{H}_{2} \mathrm{~S}$ may improve the effectiveness of EPC transplantation for reendothelialisation in nude mice $(24,28)$. Overexpression of CSE in EPCs may also increase ischemia-induced reparative function in diabetic mice (11). Until now, little data has been available to demonstrate the effects of shear stress on $\mathrm{H}_{2} \mathrm{~S}$ production and CSE expression in human EPCs.

As described previously (25), applying a modified biomedical device to stimulate EPCs seeded on artificial vessels. To evaluate the effect of shear stress on $\mathrm{H}_{2} \mathrm{~S}$ production and CSE expression in human EPCs,cells were exposed to various degrees of shear stress; when shear stress was raised from 5 to $25 \mathrm{dyn} / \mathrm{cm}^{2}$, a significant increase was observed in $\mathrm{H}_{2} \mathrm{~S}$ production. This increase in the rate of $\mathrm{H}_{2} \mathrm{~S}$ production can be separated into two distinct phases. Within $30 \mathrm{~min}$, an acute induction of $\mathrm{H}_{2} \mathrm{~S}$ production coincided with the initial increase in shear stress. After $30 \mathrm{~min}$, shear stress was maintained a prolonged phase of $\mathrm{H}_{2} \mathrm{~S}$ production, which lasted for up to $3 \mathrm{~h}$. These findings suggest that the intensity of both the acute and prolonged phases of $\mathrm{H}_{2} \mathrm{~S}$ production is reliant on the graded level of shear stress, which corresponds to a similar phenomenon that was identified in a previous study on mature endothelial cells (22).

The release of most endogenous $\mathrm{H}_{2} \mathrm{~S}$ in vasculature is likely to be dependent on CSE activity and expression (12). These experiments showed that, by increasing shear stress from $5-25 \mathrm{dyn} / \mathrm{cm}^{2}$ for $30 \mathrm{~min}$, CSE activity expression in human EPCs as a response to shear stress was both dosedependent and significantly up-regulated. Increases in CSE mRNA and protein expression were also observed to occur later than any increase in $\mathrm{H}_{2} \mathrm{~S}$ production. These observations indicate that CSE activity (with the exception of CSE mRNA and protein expression) is strongly 
A
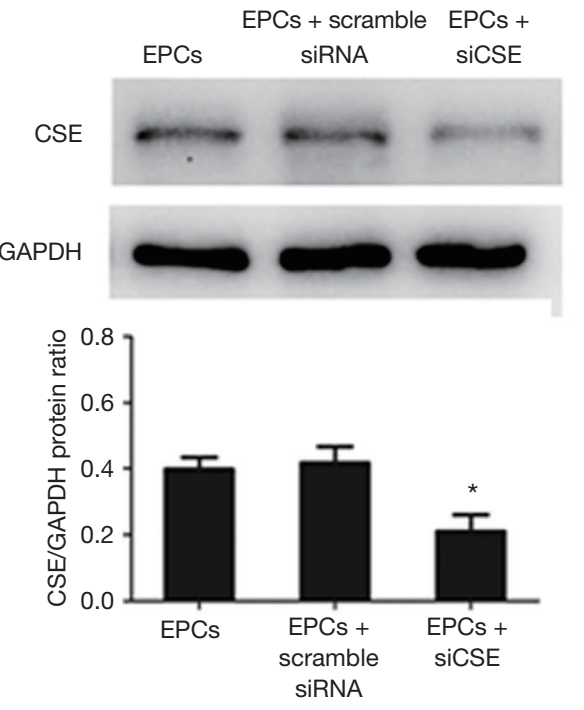

C

EPCs
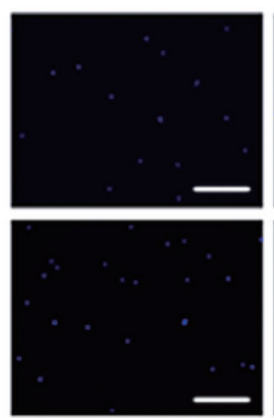

$\mathrm{SS}+\mathrm{EPCS}+$ scramble siRNA

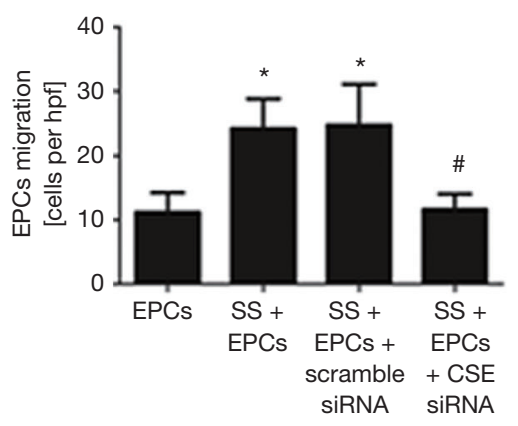

B

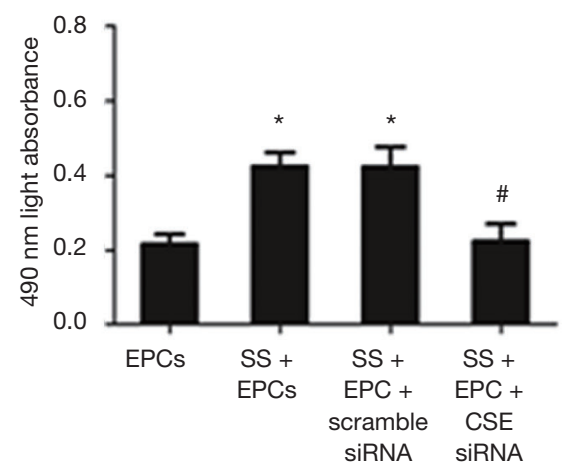

D

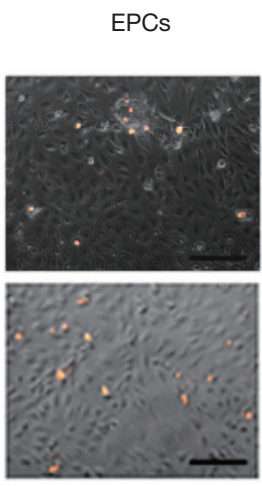

$\mathrm{SS}+\mathrm{EPCS}+$ scramble siRNA
$S S+E P C S$
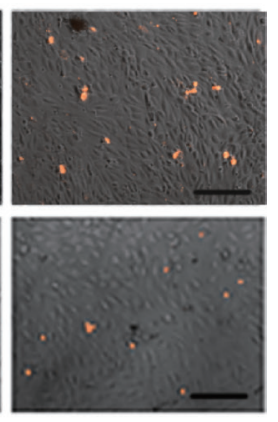

$\mathrm{SS}+\mathrm{EPCS}+$ CSE SIRNA

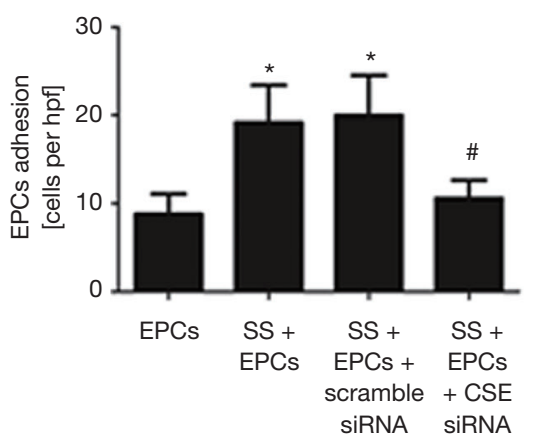

Figure 4 Effect of CSE expression on shear stress (SS)-induced functions of human EPCs. (A) Protein expression in EPCs after CSE siRNA or scrambled siRNA transduction $\left({ }^{*}, \mathrm{P}<0.05\right.$ vs. EPCs or Scrambled siRNA EPCs, $\mathrm{n}=5$ ). (B) Quantification analysis of proliferation of human EPCs by SS. ( ${ }^{*}, \mathrm{P}<0.05$ vs. EPCs, ${ }^{*}, \mathrm{P}<0.05$ vs. SS + EPCs or SS + EPCs + Scrambled siRNA, $\left.\mathrm{n}=5\right)$. (C) Representative photographs and quantification analysis of migration of human EPCs by SS $\left({ }^{*}, \mathrm{P}<0.05\right.$ vs. EPCs, ${ }^{*}, \mathrm{P}<0.05$ vs. SS + EPCs or SS + EPCs + Scrambled siRNA, n=5). (D) Representative photographs and quantification analysis of adhesion of human EPCs by SS ${ }^{*}, \mathrm{P}<0.05$ vs. EPCs, ${ }^{\#}, \mathrm{P}<0.05$ vs. SS + EPCs or SS + EPCs + Scrambled siRNA, n=5). CSE, cystathionine $\gamma$-lyase; EPC, endothelial progenitor cell. Scar bars $=100 \mu \mathrm{m}$. 
controlled by shear stress during the acute phase and during prolonged exposure to increased shear stress. Thus, it can be inferred that the post-transcriptional mechanism may contribute to the mediating effect of shear stress on CSE activity. Increasing amounts of evidence suggest that $\mathrm{H}_{2} \mathrm{~S}$ and nitrous oxide (NO) are mutually dependent in their control of vascular functions $(29,30)$. This acute surge in NO production is believed to be caused by an increase in endothelial nitric oxide synthase (eNOS) activity, most likely through increasing intracellular calcium ions $\left(\mathrm{Ca}^{2+}\right)$ concentration (31). Consequently, in future, researchers may wish to examine shear stress-mediated $\mathrm{Ca}^{2+}$ distribution or subsequently affected CSE activity. Regardless of the exact mechanisms at work, to our knowledge, this is the first study to suggest an association of up-regulation of CSE activity and expression with increased $\mathrm{H}_{2} \mathrm{~S}$ production in human EPCs in response to shear stress treatment.

eNOS-derived NO is accepted to be a key molecular target involved in EPC-mediated angiogenesis and reendothelialisation $(32,33)$. Yang et al. observed that shear stress-enhanced human EPC-mediate vascular repair was associated with the up-regulation of the phosphorylation of eNOS (26). Recently, a number of research groups, including our own, have demonstrated that both exogenous $\mathrm{H}_{2} \mathrm{~S}$ and CSE-derived $\mathrm{H}_{2} \mathrm{~S}$ need eNOS to promote the mobilisation of bone marrow EPCs $(11,24)$. In combination with the findings of this study, the above phenomena strongly suggest that CSE may be involved in the shear stress-induced alternations in function observed in EPCs in vitro. siRNA was used to down-regulate CSE expression, which was shown to reduce the increases in the migration, adhesion, and proliferation abilities of human EPCs that were induced by shear stress in vitro. Together with those of previous research $(11,26,34)$, the results of the present study indicate that the shear stress-induced enhancement of EPC functions in vitro is at least partly mediated by $\mathrm{CSE} / \mathrm{H}_{2} \mathrm{~S}$ and eNOS/NO systems. However, the precise relationship between $\mathrm{CSE} / \mathrm{H}_{2} \mathrm{~S}$ and eNOS/NO involved in EPC functions induced by shear stress is unclear and outside of the scope of this study. Therefore, our future research will endeavour to answer this question.

This study has significant repercussions regarding the avoidance and treatment of various atherosclerotic vascular diseases. EPC mobilisation, recruitment, and homing are all widely known vital aspects of reendothelialisation and angiogenesis. Further, CSE activity and expression are wellknown contributors to these positive processes $(10,11,24)$.
This study has demonstrated that EPCs can also serve as an advantageous donor of CSE following shear stress. Previous research has indicated that high levels of shear stress can lead to improved EPC efficacy in vitro as well as increased EPC-mediated reendothelialisation capacity in vivo $(18,19,20,26)$. Similarly, chronically low levels of shear stress were shown to lead to increased endothelial dysfunction in patients suffering from coronary atherosclerosis (35). The results of this study suggest that the up-regulation of CSE in EPCs with enhanced endothelium repair may be considered as an alternative mechanism responsible for the diminished incidence of shear-stress related atherosclerotic vascular diseases. Likewise, upon examination of this study's findings, it may also be hypothesised that the vascular protective effects of physical exercise do not stem solely from EPC mobilisation exerted by increased blood flow induced shear stress (36), but also from improvement of the biological phenotype of EPCs.

However, this study has a number of limitations. Although this study effectively demonstrates that shear stress causes increased $\mathrm{H}_{2} \mathrm{~S}$ production, up-regulation of CSE expression, and enhanced CSE-mediated functions of human EPCs in vitro, it is not clear whether the vascular benefits of shear stress-induced EPC-related effects in vivo also involve the $\mathrm{CSE} / \mathrm{H}_{2} \mathrm{~S}$ system. However, recent research has suggested that in vivo transplantation with diabetic EPCs overexpressing CSE improves the angiogenic activity of ischemic tissues in diabetic mice (11), which supports the possibilities put forward by our own study. Furthermore, the precise mechanisms behind increased $\mathrm{H}_{2} \mathrm{~S}$ production and CSE gene expression in human EPCs in response to shear stress are still somewhat unclear.

In conclusion, this study presents new evidence that shear stress may contribute to the biological regulation of human EPCs via increased $\mathrm{H}_{2} \mathrm{~S}$ production and CSE expression. These findings provide new molecular insights and suggest that shear stress-induced beneficial effects on vascular homeostasis are, at least in part, most likely mediated with $\mathrm{CSE} / \mathrm{H}_{2} \mathrm{~S}$ system. However, further research will be required to investigate the exact processes by which increased shear stress promotes $\mathrm{H}_{2} \mathrm{~S}$ production and CSE expression, and to determine the role of shear stress in vascular protection in relation to the changes in the CSE biological phenotype of human EPCs in vivo.

\section{Acknowledgments}

Funding: The Project was funded by the National Natural 
Science Foundation of China (No. 81700263), The Natural Science Foundation of Xinjiang (No. 2020D01C138).

\section{Footnote}

Reporting Checklist: The authors have completed the MDAR reporting checklist. Available at http://dx.doi.org/10.21037/ atm-20-6467

Data Sharing Statement: Available at http://dx.doi. org/10.21037/atm-20-6467

Conflicts of Interest: All authors have completed the ICMJE uniform disclosure form (available at http://dx.doi. org/10.21037/atm-20-6467). The authors have no conflicts of interest to declare.

Ethical Statement: The authors are accountable for all aspects of the work in ensuring that questions related to the accuracy or integrity of any part of the work are appropriately investigated and resolved. All experimental protocols in this study complied with the ethical principles laid out in the Declaration of Helsinki (as revised in 2013). The study protocol was approved by the Ethics Committee of the First Affiliated Hospital of Jinan University (Guangzhou, China). Informed consent was taken from all the subjects.

Open Access Statement: This is an Open Access article distributed in accordance with the Creative Commons Attribution-NonCommercial-NoDerivs 4.0 International License (CC BY-NC-ND 4.0), which permits the noncommercial replication and distribution of the article with the strict proviso that no changes or edits are made and the original work is properly cited (including links to both the formal publication through the relevant DOI and the license). See: https://creativecommons.org/licenses/by-nc-nd/4.0/.

\section{References}

1. Lüscher TF, Steffel J, Eberli FR, et al. Drug-eluting stent and coronary thrombosis: biological mechanisms and clinical implication. Circulation 2007;115:1051-58.

2. Inoue $\mathrm{T}$, Croce $\mathrm{K}$, Morooka $\mathrm{T}$, et al. Vascular Inflammation and Repair: Implications for Reendothelialization, Restenosis, and Stent Thrombosis. JACC Cardiovasc Interv 2011;4:1057-66.

3. Versari D, Lerman LO, Lerman A. The importance of reendothelialization after arterial injury. Curr Pharm Des 2007;13:1811-24.

4. Asahara T, Bauters C, Pastore C, et al. Local delivery of vascular endothelial growth factor accelerates reendothelialization and attenuates intima hyperplasia in balloon-injured rat carotid artery. Circulation 1995;91:2793-801.

5. Padfield GJ, Newby DE, Mills NL. Understanding the role of endothelial progenitor cells in percutaneous coronary intervention. J Am Coll Cardiol 2010;55:1553-65.

6. Huang HT, Liu ZC, Wu KQ, et al. MiR-92a regulates endothelial progenitor cells (EPCs) by targeting GDF11 via activate SMAD2/3/FAK/Akt/eNOS pathway. Ann Transl Med 2019;7:563.

7. Hur J, Yoon CH, Kim HS, et al. Characterization of two types of endothelial progenitor cells and their different contributions to neovasculogenesis. Arterioscler Thromb Vasc Biol 2004;24:288-93.

8. Vasa M, Fichtlscherer S, Aicher A, et al. Number and migratory activity of circulating endothelial progenitor cells inversely correlate with risk factors for coronary artery disease. Circ Res 2001;89:E1-7.

9. Hill JM, Zalos G, Halcox JP, et al. Circulating endothelial progenitor cells, vascular function, and cardiovascular risk. N Engl J Med 2003;348:593-600.

10. Liu F, Chen DD, Sun X, et al. Hydrogen sulfide improves wound healing via restoration of endothelial progenitor cell functions and activation of angiopoietin-1 in type 2 diabetes. Diabetes 2014;63:1763-78.

11. Cheng Z, Garikipati VN, Nickoloff E, et al. Restoration of Hydrogen Sulfide Production in Diabetic Mice Improves Reparative Function of Bone Marrow Cells. Circulation 2016;134:1467-83.

12. Polhemus DJ, Lefer DJ. Emergence of hydrogen sulfide as an endogenous gaseous signaling molecule in cardiovascular disease. Circ Res 2014;114:730-7.

13. Wang $\mathrm{Y}$, Zhao X, Jin H, et al. Role of hydrogen sulfide in the development of atherosclerotic lesions in apolipoprotein E knockout mice. Arterioscler Thromb Vasc Biol 2009;29:173-9.

14. Yang G, Wu L, Jiang B, et al. H2S as a physiologic vasorelaxant: hypertension in mice with deletion of cystathionine gamma-lyase. Science 2008;322:587-90.

15. Papapetropoulos A, Pyriochou A, Altaany Z, et al. Hydrogen sulfide is an endogenous stimulator angiogenesis. Proc Natl Acad Sci U S A 2009;106:21972-7.

16. King AL, Polhemus DJ, Bhushan S, et al. Hydrogen 
sulfide cytoprotective signaling is endothelial nitric oxide synthase-nitric oxide dependent. Proc Natl Acad Sci U S A 2014;111:3182-7.

17. Obi S, Yamamoto K, Ando J. Effects of shear stress on endothelial progenitor cells. J Biomed Nanotechnol 2014;10:2586-97.

18. Obi S, Masuda H, Shizuno T, et al. Fluid shear stress induces differentiation of circulating phenotype ebdothelial progenitor cells. Am J Physiol Cell Physiol 2012;303:C595-606.

19. Xia WH, Yang Z, Xu SY, et al. Age-Related Decline in Reendothelialization Capacity of Human Endothelial Progenitor Cells Is Restored by Shear Stress. Hypertension 2012;59:1225-31.

20. Hu Q, Zhang T, Li Y, et al. $\beta 2$ AR-dependent signaling contributes to in-vivo reendothelialization capacity of endothelial progenitor cells by shear stress. J Hypertens 2020;38:82-94.

21. Yang Z, Tao J, Wang JM, et al. Shear stress contributes to $\mathrm{t}$-PA mRNA expression in human endothelial progenitor cells and nonthrombogenic potential of small diameter artificial vessels. Biochem Biophys Res Commun 2006;342:577-84.

22. Huang B, Chen CT, Chen CS, et al. Laminar shear flow increases hydrogen sulfide and activates a nitric oxide producing signaling cascade in endothelial cells. Biochem Biophys Res Commun 2015;464:1254-9.

23. Ke X, Shu XR, Wu F, et al. Overexpression of $\beta 2 A R$ gene improves function and re-endothelialization capacity of EPCs after arterial injury in nude mice. Stem Cell Res Ther 2016;7:73.

24. Hu Q, Ke X, Zhang T, et al. Hydrogen sulfide improves vascular repair by promoting endothelial nitric oxide synthase dependent mobilization of endothelial progenitor cells. J Hypertens 2019;37:972-84.

25. Chen K, Fan W, Wang X, et al. MicroRNA-101 mediates the suppressive effect of laminar shear stress on mTOR expression in vascular endothelial cells. Biochem Biophys Res Commun 2012;427:138-42.

26. Yang Z, Xia WH, Zhang YY, et al. Shear stress-induced activation of Tie2-dependent signaling pathway enhances

Cite this article as: Hu Q, Zhang B, Liu Y, Guo Y, Zhang T, Nie R, Ke X, Dong X. The effect of fluid shear stress in hydrogen sulphide production and cystathionine $\gamma$-lyase expression in human early endothelial progenitor cells. Ann Transl Med 2020;8(20):1318. doi: 10.21037/atm-20-6467 reendothelialization capacity of early endothelial progenitor cells. J Mol Cell Cardiol 2012;52:1155-63.

27. Yang G, Wu L, Wang R. Pro-apoptotic effect of endogenous H2S on human aorta smooth muscle cells. FASEB J 2006;20:553-5.

28. Ke X, Zou J, Hu Q, et al. Hydrogen SulfidePreconditioning of Human Endothelial Progenitor Cells Transplantation Improves Re-Endothelialization in Nude Mice with Carotid Artery Injury. Cell Physiol Biochem 2017;43:308-19.

29. Coletta C, Papapetropoulos A, Erdelyi K, et al. Hydrogen sulfide and nitric oxide are mutually dependent in the regulation of angiogenesis and endothelium-dependent vasorelaxation. Proc Natl Acad Sci U S A 2012;109:9161-6.

30. Altaany Z, Yang G, Wang R. Crosstalk between hydrogen sulfide and nitric oxide in endothelial cells. J Cell Mol Med 2013;17:879-88.

31. Fleming I, Busse R. Molecular mechanisms involved in the regulation of the endothelial nitric oxide synthase. Am J Physiol Regul Integr Comp Physiol 2003;284:R1-12.

32. Aicher A, Heeschen C, Mildner-Rihm C, et al. Essential role of endothelial nitric oxide synthase for mobilization of stem and progenitor cells. Nat Med 2003;9:1370-6.

33. Everaert BR, Van Craenenbroeck EM, Hoymans VY, et al. Current perspective of pathophysiological and interventional effects on endothelial progenitor cell biology: focus on PI3K/AKT/eNOS pathway. Int J Cardiol 2010;144:350-66.

34. Tao J, Yang Z, Wang JM, et al. Effects of fluid shear stress on eNOS mRNA expression and NO production in human endothelial progenitor cells. Cardiology 2006;106:82-8.

35. Kumar A, Hung OY, Piccinelli M, et al. Low Coronary Wall Shear Stress Is Associated With Severe Endothelial Dysfunction in Patients With Nonobstructive Coronary Disease. JACC Cardiovasc Interv 2018;11:2072-80.

36. Laufs U, Werner N, Link A, et al. Physical training increases endothelial progenitor cells, inhibits neointima formation, and enhances angiogenesis. Circulation 2004;109:220-6.

(English Language Editor: J. Reynolds) 
Supplementary

Table S1 Sequence of siRNA primers

\begin{tabular}{lcc}
\hline Gene & siRNA & Sequence \\
\hline CSE & Sense strand & 5'-GGUUAUUUAUCCUGGGCUGdTdT-3' \\
& Antisense strand & 5'-CAGCCCAGGAUAAAUAACCdTdT-3' \\
\hline
\end{tabular}

Table S2 Sequence of oligonucleotide primers

\begin{tabular}{lcc}
\hline Gene & Oligonucleotide & Sequence \\
\hline CSE & Sense & 5'-CCCCACAAACCCCACCCAGAA-3' \\
& Antisense & 5'-GACACCAGGCCCATTAC-3' \\
GAPDH & Sense & 5'-GGTGGTCTCCTCTGACTTCAACA-3' \\
& Antisense & 5'-GTTGCTGTAGCCAAATTCGTTGT-3' \\
\hline
\end{tabular}

